\title{
Rice Blast in Puerto Rico ${ }^{1}$
}

\author{
Lii-Jang Liu $^{2}$ \\ ABSTRACT
}

Rice blast, which had not been observed during the last six decades in Puerto Rico, reappeared recently in Manatí and in the Gurabo Substation, affecting Brazos, a cultivar introduced from Texas. Pathogenicity tests, as well as studies on the conidial morphology, showed that the fungus isolated from typical blast lesions is Pyricularia oryzae Cav. The physiology of the fungus and its sporulation on various media also were studied. The optimum temperature range, both for mycelial growth and for germination of conidia, was found to be between 24 to $28^{\circ} \mathrm{C}$. Sporulation occurred satisfactorily on potato-dextrose agar enriched with coconut milk, and on steamed corn and barley, and rice-straw-decoction agars. In vitro tests with fungicides benomyl, pentachloronitrobenzene, mancozeb, chloroneb, and captan indicated that the first two compounds are the most effective in inhibiting mycelial growth of $P$. oryzae.

\section{INTRODUCTION}

Rice blast, caused by Pyricularia oryzae Cav. is a disease of great economic importance in Asia, as well as in Latin America, where rice is a major source of carbohydrates in the diet. Blast is widely distributed in the rice-growing countries of the world. The disease has been reported in Argentina (12), Brazil (10), British Guiana (1), Colombia (2), Costa Rica (9), Cuba (3), the Dominican Republic (6), El Salvador (5), Guatemala (8), Mexico (19), Nicaragua (11), Panamá (13), and Perú (14). It occurs mostly under conditions of intensive cultivation and high levels of nitrogen fertilization.

Although rice blast was reported some 58 years ago in Puerto Rico by Stevenson (15) and Thomas (17), the incidence of the disease did not cause concern. Lately, new rice cultivars have been introduced into Puerto Rico from the United States and other rice-growing countries. Brazos, a cultivar newly released in Texas, was found severely infected by Pyricularia sp. in the Manatí area.

The information on isolation, pathogenicity, conidial morphology, physiology, as well as in vitro relative sensitivity of the Puerto Rican isolates of $P$. oryzae to various fungicides, is presented in this report.

\section{MATERIALS AND METHODS}

Plants of rice cultivars Brazos, Chontalpa, Blue Bonnet 50, Girona, and Bahía, grown in a 1:1 steam-sterilized mixture of soil and filter press cake,

${ }^{1}$ Manuscript submitted to Editorial Board December 21, 1977.

${ }^{2}$ Phytopathologist, Agricultural Experiment Station, Mayagüez Campus, University of Puerto Rico, Río Piedras, P.R. The author is grateful to Mr. José Vicente-Chandler, Mr. Fernando Abruña, and Mr. Servando Silva, ARS-USDA, for providing seeds of rice cultivars and for their cooperation. The author is also grateful to Dr. Guillermo Gálvez-E., Plant Pathologist CIAT, Cali, Colombia, S.A., for his valuable suggestion on the use of coconut milk enriched medium for isolation. 
(12 pots per cultivar) were inoculated by spraying them, using a fine atomizer, with a water suspension of fresh collected conidia (about 10 conidia per $100 \times$ microscope field). The inoculated plants were divided into two groups (six pots per group). One group was kept in a moist chamber with saturated air for $24 \mathrm{~h}$ and the other group was placed in a ventilated greenhouse. After incubation, the seedlings in the moist chamber were transferred to a ventilated greenhouse at 28 to $32^{\circ} \mathrm{C}$. Blast symptoms in both groups of plants were recorded 10 days after inoculation.

In the studies on the effect of temperature on germination of $P$. oryzae, washed conidia were secured from a culture grown on potato-dextrose agar (PDA) enriched with coconut milk. The conidia were transferred to petri dishes containing double-distilled water. Three dishes containing the conidia were incubated at each of the following temperatures: 8,12 , $16,20,24,28,32$, and $36^{\circ} \mathrm{C}$.

In the studies on the effect of temperature on mycelial growth, a monoconidial isolate of $P$. oryzae was grown on PDA at 8, 12, 16, 20, 24, 28,32 , and $36^{\circ} \mathrm{C}$. For each temperature, three petri dishes containing 15 $\mathrm{ml}$ of the PDA-coconut milk medium were seeded with a $2 \mathrm{~mm}$ culture disc of the isolate. The disc was cut with a sterile cork borer from the advancing margin of colonies grown on PDA. The dishes containing the inoculum were incubated at different temperatures for 8 days. The increment in the diameter of colonies was measured at the end of the incubation period.

In the studies on the effect of culture media on sporulation the following media were tested: potato-dextrose agar (PDA), coconut-milk-enriched potato-dextrose agar (CEPDA) (39 g PDA and $1000 \mathrm{ml}$ of medium), steamed barley (SB) (12 g barley $+15 \mathrm{ml}$ water), steamed corn (SC) (12 $\mathrm{g}$ corn $+15 \mathrm{ml}$ water) and rice-straw-decoction agar (RSDA) (100 g of rice straw $+39 \mathrm{~g}$ PDA $+10 \mathrm{~g}$ sucrose per $1000 \mathrm{ml}$ of medium). A $2 \mathrm{~mm}$ culture disc of the monoconidial isolate of $P$. oryzae was placed in the center of each plate, using 10 plates per medium. The seeded plates were then incubated at $28^{\circ} \mathrm{C}$. The number of conidia per microscope field (100 $\times$ ) was recorded at the end of 10-day incubation period.

Fungicides benomyl, pentachlorobenzene (PCNB), mancozeb, chloroneb and captan were assayed in vitro in the laboratory, at $0.05,0.25,0.5$, and $1.0 \%$ concentrations, for their toxicity against $P$. oryzae. The fungus was grown on PDA medium to which four 2-mm paper discs containing varying concentrations of the active ingredients of the five fungicides were added. Paper discs containing no fungicide were added to the plates used as controls. For each concentration, three petri dishes were used. The plates containing the paper discs were then incubated at $28^{\circ} \mathrm{C}$. The diameter of the colonies was measured at the end of a 5-day incubation period. 


\section{RESULTS AND DISCUSSION}

\section{DESCRIPTION OF SYMPTOMS}

In the early stage of disease development, the affected plants of cultivar Brazos showed circular to irregular, minute yellowish-brown spots on both sides of the leaf. These spots soon became dark brown with reddish borders and measured 2 to $3 \mathrm{~mm}$ long $\times 1$ to $2 \mathrm{~mm}$ wide. Sometimes, these spots were confluent, forming stripes with straw-colored centers. In the advanced stage, the affected plants in the field showed typical

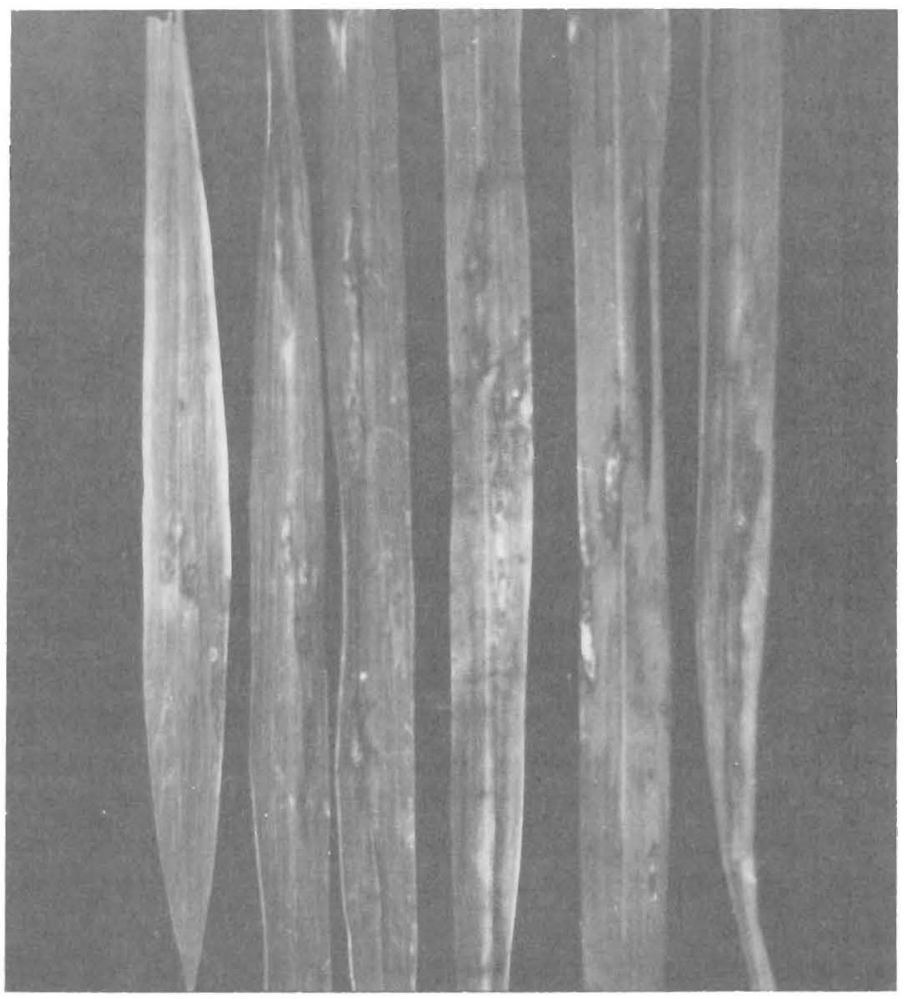

Fig. 1.-Symptoms of the blast disease on rice leaves in the field.

elliptical blast lesions which measured 3 to $40 \mathrm{~mm}$ long $\times 2$ to $5 \mathrm{~mm}$ wide. These lesions were usually confined by two main veins and had large necrotic gray centers with brown or reddish-brown margins (fig. 1). The affected seedlings showed a general blasting effect resembling herbicide injury (fig. 2).

\section{CULTURAL APPEARANCE AND MORPHOLOGY OF THE CAUSAL FUNGUS}

The appearance of the fungus colony on PDA enriched with coconut milk was dark grayish-green with a light margin (fig. 3). Conidia were 
pyriform and three-celled with a basal appendage (fig. 4). However, the size of the conidia varied considerably, depending upon the culture media, as well as age of the leaf lesions. Conidia formed on steamed-corn measured 21.2 to $34 \mu$ long $\times 8.5$ to $11.9 \mu$ wide. Conidia produced on

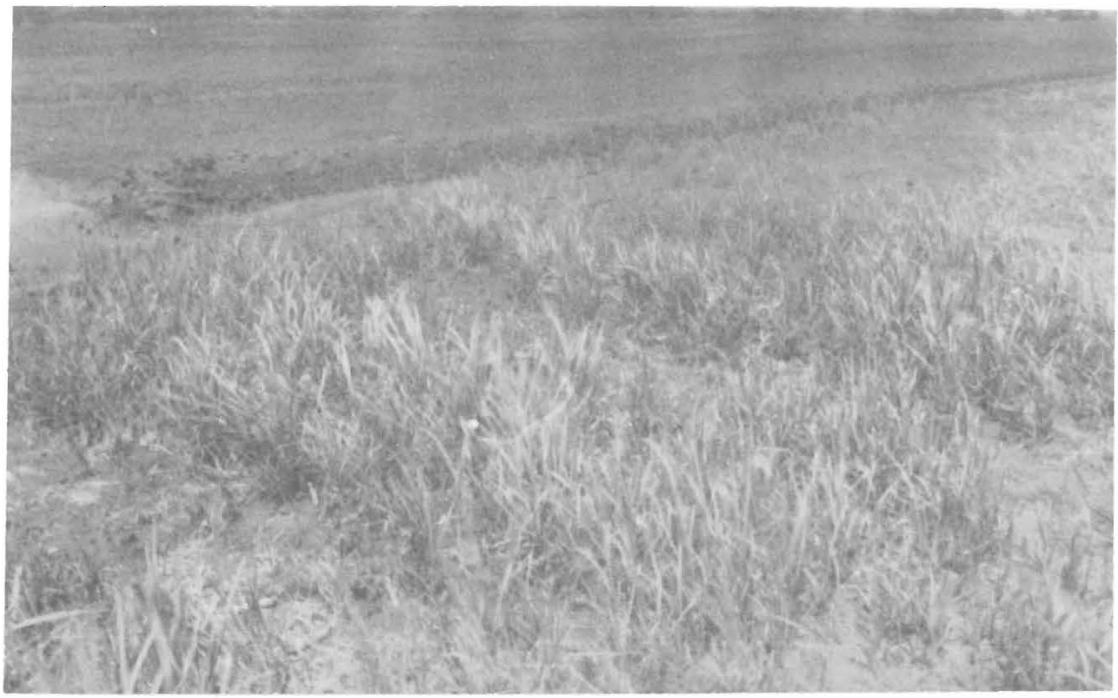

Fig. 2.-Blasting effect of Pyricularia oryzae on seedlings in the Manatí area.

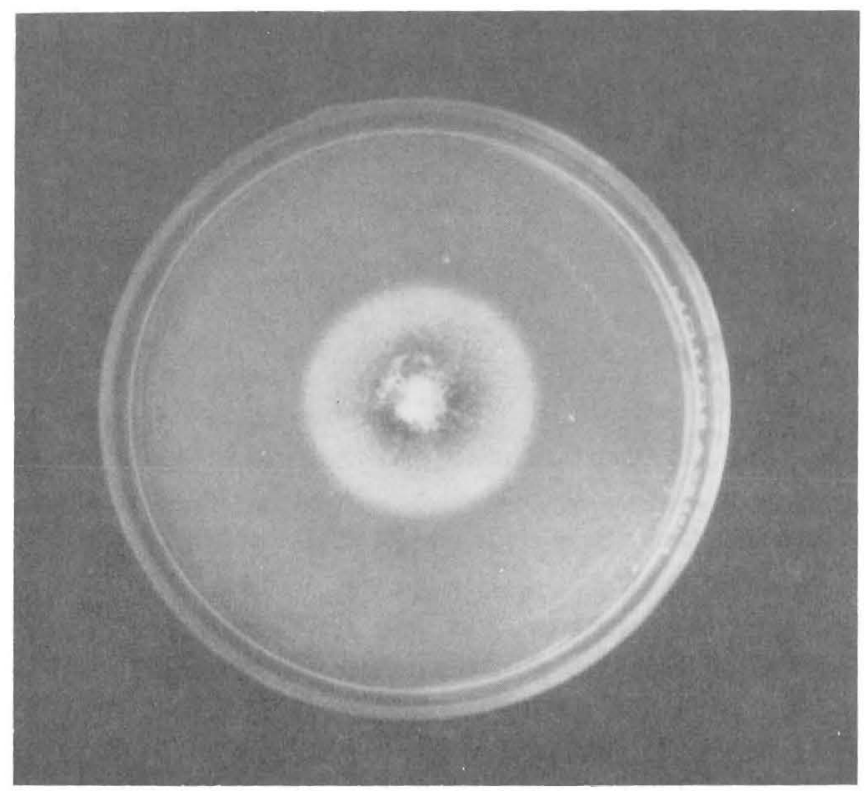

Frg. 3.-Cultural appearance of Pyricularia oryzae on coconut-enriched potato-dextrose agar after 5 -day incubation at $28^{\circ} \mathrm{C}$. 


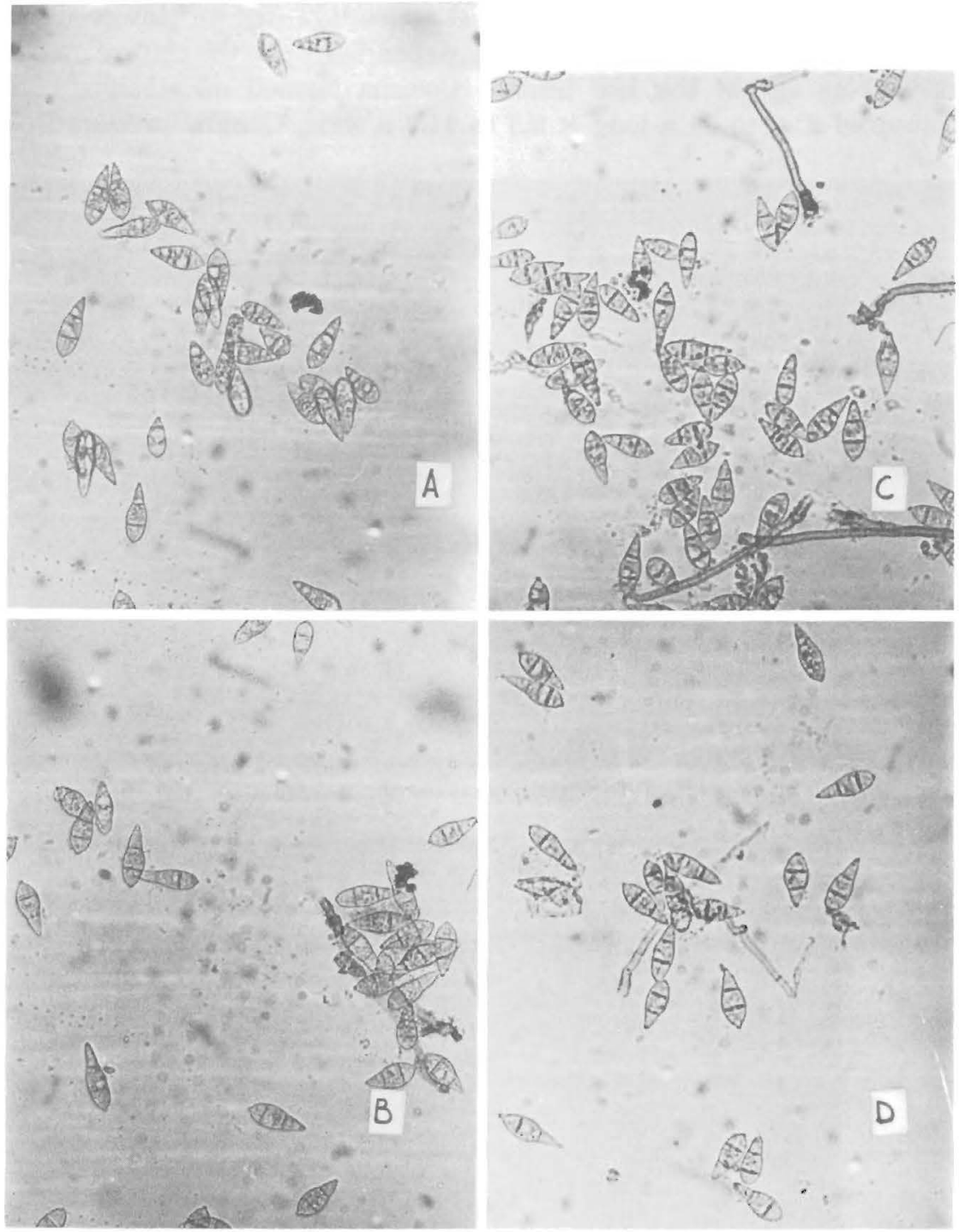

FIG. 4.-Conidia of Pyricularia oryzae isolated from rice plants showing symptoms of blast: $\mathrm{A}$ and $\mathrm{B}$, conidia from young leaf lesions; C and D, conidia from old leaf lesions.

steamed-barley grains measured 25.5 to $29.7 \mu$ long $\times 8.5$ to $11.9 \mu$ wide. Conidia from young leaf lesions measured 21.5 to $32 \mu$ long $\times 9.5$ to 12.5 $\mu$ wide and appeared normal and healthy (fig. $4 \mathrm{~A}$ and B). Conidia from the old-leaf lesions measured 22.5 to $34 \mu$ long $\times 8.5$ to $12.8 \mu$ wide, and appeared to be devoid of cell contents (fig. $4 \mathrm{C}$ and D). Generally 
speaking, conidia from culture media such as coconut-milk-enriched PDA tended to be more slender than those from leaf lesions (fig. $5 \mathrm{~A}$ and B). Furthermore, as cultures aged, the conidia appeared fatter and the mycelium thicker (fig. $5 \mathrm{C}$ and D).
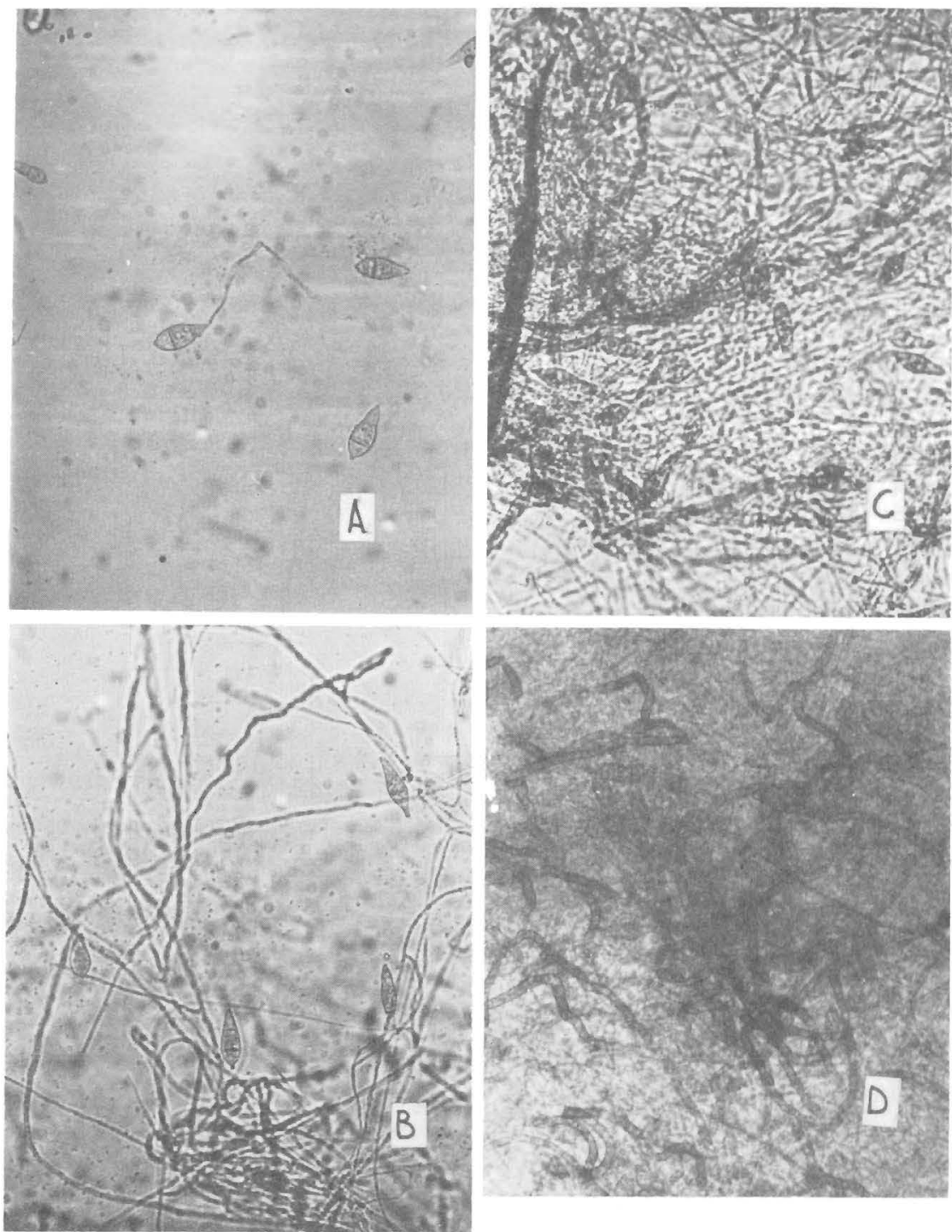

FIG. 5.-Conidia of Pyricularia oryzae on culture medium: A, germination of conidia on coconut-enriched potato-dextrose agar (CEPDA); B, sporulation of P. oryzae on 4-day old CEPDA; C, sporulation on 8-day old CEPDA; and D, sporulation on 12-day old CEPDA. Note the formation of thick-walled mycelium. 


\section{EFFECT OF TEMPERATURE ON GERMINATION}

The optimum temperature range for germination of conidia from $P$. oryzae was found to be from $24^{\circ}$ to $28^{\circ} \mathrm{C}$ (fig. 6). At $28^{\circ} \mathrm{C}$, initiation of germination was observed in about $5 \mathrm{~h}$. The process reached a maximum of $80 \%$ in 5 days. According to Sueda (16), the optimum temperature for germination of conidia was found to be $25^{\circ}$ to $28^{\circ} \mathrm{C}$. The results herein reported agree with Sueda's findings.

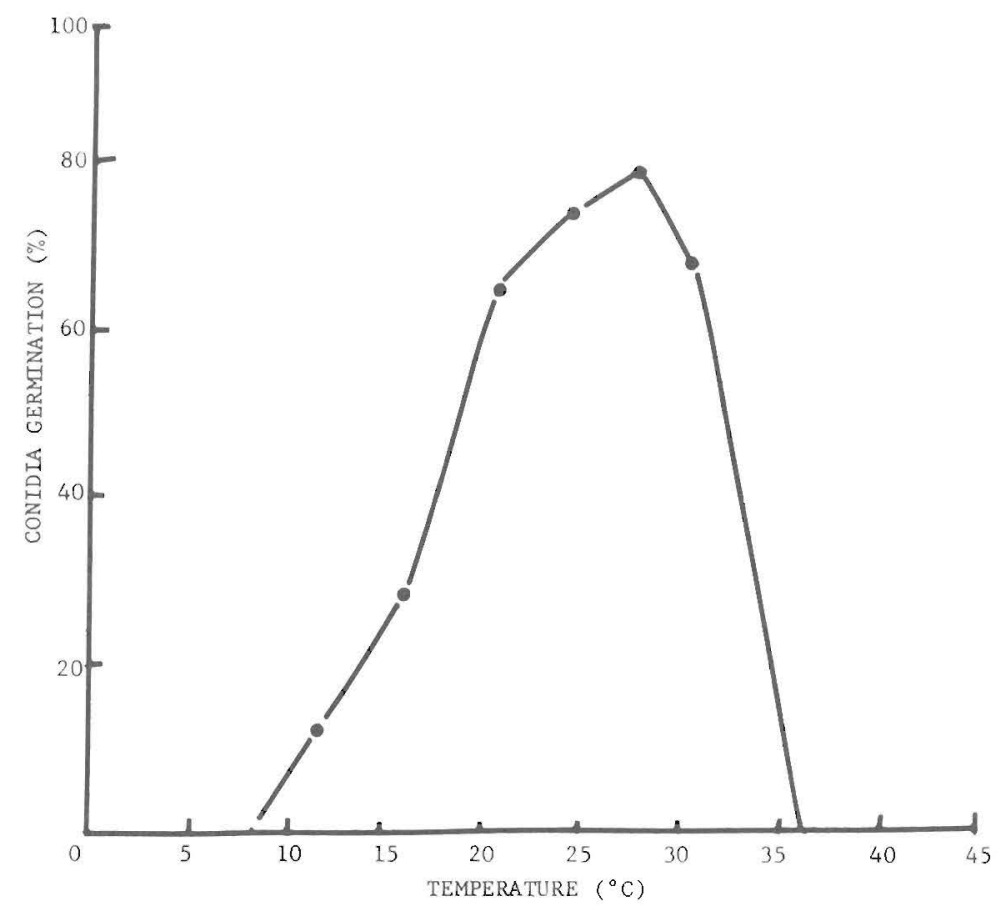

FIG. 6.-Percent of conidia germination of Pyricularia oryzae after a 2-day incubation in double-distilled water at different temperatures.

EFFECT OF TEMPERATURE ON MYCELIAL GROWTH

The optimum temperature range for mycelial growth of $P$. oryzae was found to be between $24^{\circ}$ and $28^{\circ} \mathrm{C}$. No growth was observed at $8^{\circ}$ nor at $36^{\circ} \mathrm{C}$ (fig. 7). Yoshii (18), in his studies concerning effect of temperature on mycelial growth, observed that the optimum temperature for mycelial growth within a given length of time was $26^{\circ}$ to $28^{\circ} \mathrm{C}$.

EFFECT OF CULTURE MEDIA ON SPORULATION

No conidia were formed on PDA. Only mycelial growth was observed. The maximum production of conidia per microscope field (9.5) occurred 
on CEPDA, while the lowest number (5.0) was found on rice-strawdecoction agar (fig. 8).

\section{PATHOGENICITY TESTS}

Blast symptoms appeared on rice plants which were placed in the moist chamber with saturated air, whereas no symptoms were observed on

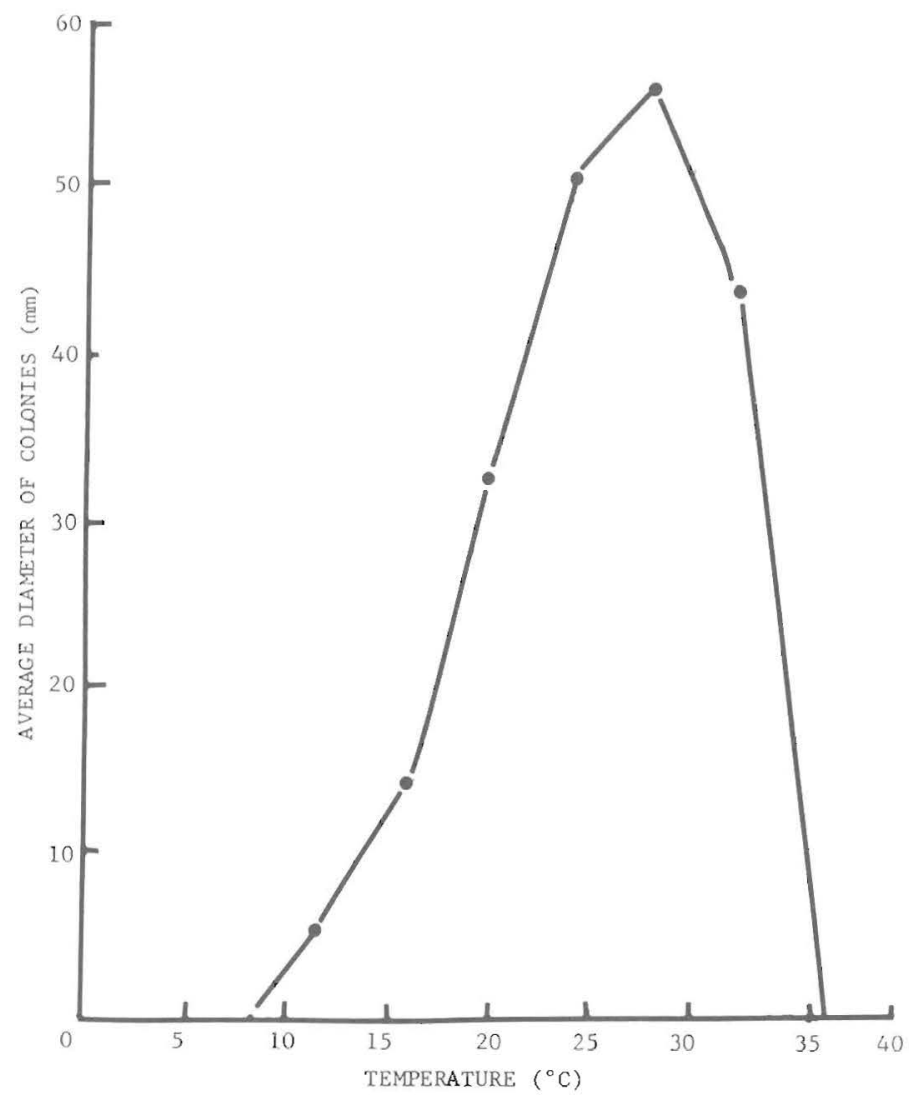

FIG. 7.-Size of colonies of monoconidial isolate of Pyricularia oryzae after an 8-day incubation on potato-dextrose agar at different temperatures.

plants which were left out of the chamber. A saturated air favors the infection of rice by $P$. oryzae. In the field, blast was observed more frequently in densely populated fields, in which, presumably, air humidity is higher.

Among the cultivars tested, Brazos seemed to be the most susceptible and Girona the least susceptible. The lesions on Brazos were elliptical (or lenticular), with large necrotic gray centers and with brown or reddish- 


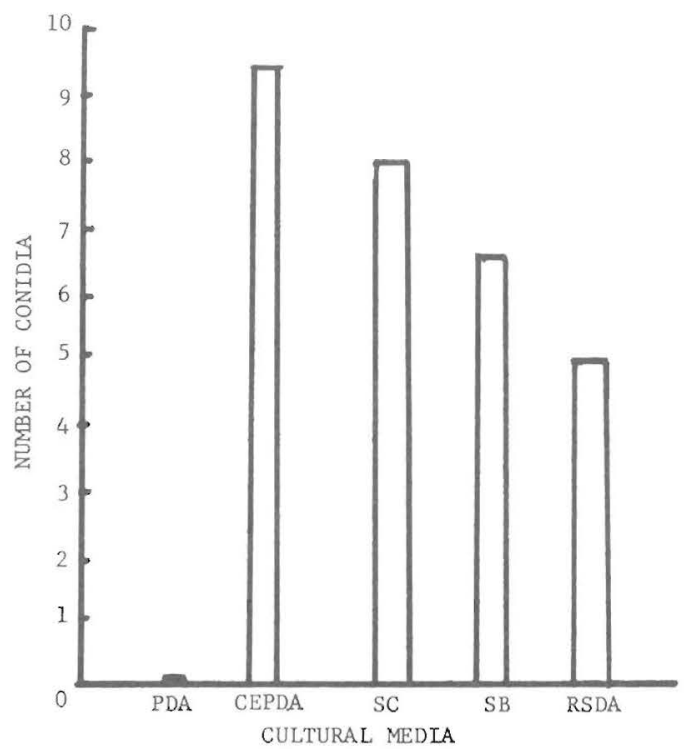

Fig. 8.-Number of conidia of Pyricularia oryzae observed after a 10-day incubation in a microscope field $100 \times$ on various culture media $(\mathrm{PDA}=$ potato-dextrose agar; CEPDA = coconut-enriched potato-dextrose agar; $\mathrm{SC}=$ steamed corn; $\mathrm{SB}=$ steamed barley; RSDA = rice-straw decoction agar).

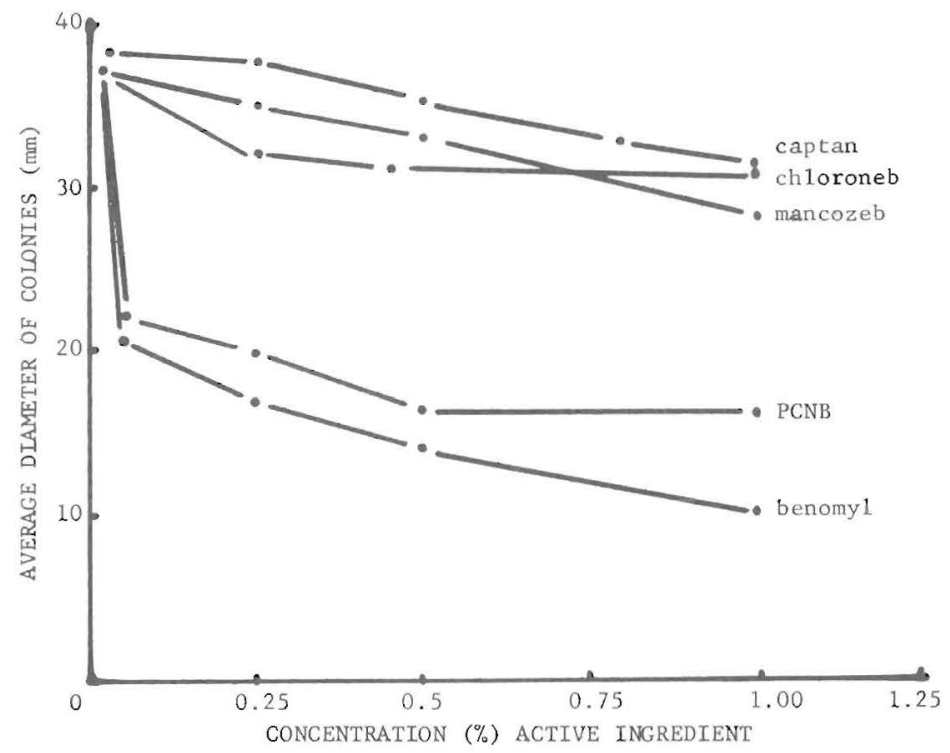

FiG. 9.-Effect of various fungicides (benomyl, PCNB, mancozeb, chloroneb, and captan) on mycelial growth of Pyricularia oryzae from rice. 
brown margins. Approximately $3 \%$ of the leaf area was damaged. The lesions on Blue Bonnet 50 were small, roundish with necrotic gray centers surrounded by brown margins. On Chontalpa the lesions were restricted to brown specks. On both Bahía and Girona, small brown specks of pinhead size were evident. In addition, the blasting effect, i.e., killing or yellowing of the leaves, occurred on Brazos, Blue Bonnet 50, and Chontalpa, but not on Bahía and Girona. The fungus was isolated from the inoculated seedlings.

\section{IN VITRO FUNGICIDE TESTS}

Benomyl and PCNB appeared to be the most effective fungicides for inhibiting mycelial growth of $P$. oryzae (fig. 9). This finding agrees with that of Gálvez and Castaño, who in 1972 observed that benomyl (Benlate) $)^{3}$ was effective in the control of blast in Colombia. In Costa Rica, Carrera (4) reported better blast control with benomyl than with mancozeb (Dithane M-45).

\section{RESUMEN}

La pudricion de la base de la panoja del arroz, enfermedad conocida también por quema del arroz y brusone, que no había aparecido en Puerto Rico en las útimas seis décadas, reapareció recientemente en Manatí y en la Subestación Experimental de Gurabo, atacando al cultivar Brazos, introducido de Texas. Pruebas de patogenicidad, así como estudios morfológicos de los conidios, indicaron que el hongo aislado de lesiones típicas de esta enfermedad es Pyricularia oryzae Cav. Se estudiaron la fisiología del hongo y su esporulacíon en varios medios de cultivo. La temperatura óptima, tanto para el desarrollo filamentoso como para la germinación de los conidios, osciló entre 24 y $28^{\circ} \mathrm{C}$. La esporulación fue satisfactoria en agar con dextrosa y papa, enriquecido con leche de coco, en maíz y cebada cocidos al vapor y en agar con una decocción de paja de arroz. Pruebas in vitro con los fungicidas benomyl, pentacloronitrobenzeno, mancozeb, chloroneb y captan, indicaron que los primeros dos son los más eficaces para inhibir el desarrollo filamentoso de $P$. oryzae.

\section{LITERATURE CITED}

1. Bancroft, C. K., 1954. Diseases in plants, with special reference to fungi parasitic on crops in British Guiana, British Guiana J. Board Agric. 11: 47-57, 1918 (USDA Mycol. Dis. Ser. Spec. Publ. 6: 17.

2. Calle, L. E., 1935. Monografía sobre el cultivo del arroz en el Valle del Cauca, Enfermedades del arroz, Bol. Agric. Medellín 201: 225-9, (USDA Mycol. Dis. Ser. Spec. Publ. 6: 26, 1954).

3. Calvino, M., 1919. Informe An. Esta. Exp. Agron, (Cuba) 1917-1918, p. 439, (USDA Mycol. Dis. Ser. Spec. Publ. 6: 26, 1954).

4. Carrera, M., 1975. Evaluación de fungicidas en el control de Piricularia oryzae Cav. en la zona del Pacífico seco_Guanacaste, Costa Rica, XXI Reunión Anual PCCMCA 2: $473-9$,

5. Crandall, B. S., Abrego, L., and Patino, B., 1951. A check list of diseases of economic plants of El Salvador, Central America, Plant Dis. Rep. 35(2): 545-54.

${ }^{3}$ Trade names are used in this publication solely for the purpose of providing specific information. Mention of a trade name does not constitute a guarantee or warranty of equipment or materials by the Agricultural Experiment Station of the University of Puerto Rico or an endorsement over other equipment or materials not mentioned. 
6. Faris, J., 1923. Enfermedades de los productos de valor económico, Rev. Agric. Santo Domingo 17: 161-7, 177-87, (USDA Mycol. Dis. Ser. Spec. Publ. 6: 41, 1954).

7. Gálvez-E., G. E., and Castaño-Z., J., 1972. Aplicación de fungicidas al suelo y al follaje para el control de la piricularia (Pyricularia oryzae) en arroz, Phytopathology 62(7): 758.

8. Guatemala Inst. Agropecu. Nac., 1949. Report for the period January to June, 1948, p. 36.

9. Hastings, K., 1954. Presence of the two most destructive rice pathogens in Costa Rica, Plant Dis. Rep. 33(11): 439-40 (USDA Mycol. Dis. Ser. Spec. Publ. 6: 55).

10. Hempel, A., 1910. Molestias de arroz, Bol. Tech. Inst. São Paulo 2(12): 305-90, (USDA Mycol. Dis. Ser. Spec. Publ. 6: 59, 1954).

11. Litzenberger, S. C. and Stevenson, J. A., 1957. A preliminary list of Nicaraguan plant diseases, Plant Dis. Rep. Suppl. 243, 19 p.

12. Lizer, C., 1954. Quelques notes pour servir de complément au recueil de N. HaumanMerch sur "les parasites végétaux de plantes cultivées en Argentina et dans des regions limitrophes", An. Soc. Cient. Argent. 78: 5-17 (USDA Mycol. Dis. Ser. Spec. Publ. 6: 76.

13. Orton, C. R., 1954. Dominio de las enfermedades de las plantas que se transmiten con las semillas, Unión Panam. Ser. Agric. 56: 836-60 (USDA Mycol. Ser. Spec. Publ. 6: 97.

14. Revilla, V. A., 1953. El quemado o brusone del arroz en el Perú (English summary), Esta. Agric. La Molina, Informe 86, 16 p. (Rev. Appl. Mycol. 33: 378.

15. Stevenson, J. A., 1918. A check list of Puerto Rican fungi and a host index, J. Dep. Agric. P.R. 2: 125-264.

16. Sueda, H., 1928. Studies on the rice blast disease, Rep. Dep. Agric. Gov. Res. Inst., Formosa 36: 1-130.

17. Thomas, H. E., 1917. Puerto Rico Agric. Exp. Stn. Rep. 1: 28-30 (USDA Mycol. Dis. Ser. Spec. Publ. 6: 131, 1954).

18. Yoshii, H., 1936. Pathological studies of rice blast caused by Piricularia oryzae I. Some studies on the physiology of the pathogen. II. The mode of infection of the pathogen, Ann. Phytopathol. Soc., Japan 6: 199-218.

19. Zenteno-Zevada, M., Yerkes, W. D., and Niederkauser, J. S., 1955. Primera lista de hongos de México arreglada por huéspedes (First list of Mexican fungi arranged under hosts), Foll. Tec. Ofic. Esta. Exp. México, 43 p. 